\title{
JOHN LOCKE'S CONCEPT OF STATE: A PANACEA FOR THE CHALLENGES OF NIGERIA DEMOCRACY
}

\author{
John-Paul Chinedu Enemuo* \\ http://dx.doi.org/10.4314/og.v15i1.14s
}

\begin{abstract}
Nigerian form and practice of democracy is very faulty, ranging from the foundation to the very level of the actual practice of democracy. Most political office holders in Nigeria arrive at the corridors of power through avenues devoid of generally accepted standard of democratic principle, it is in Nigeria that one gets to hear and see that power is actually taken and not given as is provided by the principles of democracy. John Locke in his political theory presented consent as the bedrock of democracy and went further to outline the aims of civil government. Consequently, any civil government that deviates from the provisions of the social contract theory, stands the risk of dissolution. From the foregoing, the reverse is the case in the Nigerian socio-political space. This work makes use of analytical method in philosophy to investigate the shortcomings in the characteristics of democracy being practiced in Nigeria, it would analyze John Locke's concept of the state placing it in line with current trends in the Nigerian political scene. The researcher discovered that what is practiced in Nigeria falls short, far below standard of what is generally known and practiced worldwide as democracy which by implication is the "government of the people, by the people and for the people, viewing it through the lens and window of Lockean provision. Finally, this paper concludes that Nigeria politicians and office holders should eschew selfishness and pursue that which would contribute positively to the commonwealth. Democracy is people/masses oriented. Once a nation misses this target, the glory of that nation automatically starts corroding and subsequently fades away, and the result is seen in the gross suffering of the citizens.
\end{abstract}

Keywords: Democracy, Politics, Nigeria, Power, Government. 
Enemuo: John Locke's Concept of State: A panacea for the challenges...

\section{Introduction}

Aristotle stated categorically in his discussion about political thought that "it is evident that the state is a creature of nature, and man is a political animal." This did not necessarily imply man is a politician, but that man can only attain good life if he lives in a polis or city/ state (society). What this means is that it is inevitable for man to exist outside the confines of the society or within the radius of fellow men. In buttressing this, Aristotle went further to submit that "he who is unable to live in a society or who has no need because he is sufficient for himself must either be a beast or a god"2.

Consequently, it is now very obvious and beyond doubt that man flourishes optimally in a state, the giant question emerges: who rules the state and secondly how best is the state going to be managed. Incidentally, this has been this has been the major issue that strives to bring Nigerian democracy to her knees. The issue of leadership and from where it would come from: Hausa, Yoruba or Igbo has remained a great injury that is not ready to be healed in any foreseeable or proximate feature. Nigeria has reduced her democracy and mode of leadership to a faulty zoning arrangement hence sacrificing competency at the altar of tribalism. The second is how best the state is going to be managed, this proceeds from 'who rules the state', when 'who rule the state' becomes faulty, how the state is going to be managed becomes dangerously affected and consequently damaged.

Divergent schools of thought have come up with various systems of government ranging from monarchy, oligarchy, tyranny/Machiavellism, aristocracy and democracy. All these schools of thought were actually making efforts on how best to attain the lowest possible risk in preservation of human life and other rights and properties of individuals hence the coming together men to reduce the excesses of men. Little wonder Russell opined that "every community is faced with two dangers, anarchy and despotism", Nigeria has in principle chosen democracy and in practice does some other thing quite inimical to democracy. Man constitutes the state and it is man that must be at the helm of affairs of fellow man, so the question is how and by what means should man come to power. Should it be by force, warfare, baboon blood fight, threats of making the government ungovernable, or manipulating his political opponents. Each country clamors to be 
identified with the term democracy and Nigeria is isolated in this, the problem is to what extent do Nigerian leaders understand democracy and it attendant principles. What is seen in the present day Nigerian democracy is a system of government that is not far from military dictatorship. What plays is power affluence, imprisonment of the opposition, incessant embezzlement of public fund, lack of integrity, assassination, massive rigging of election, impeachment, economic instability, excessive violation of human right. The type of democracy that is obtainable in Nigeria is one devoid of morality as against the stipulations of ancient philosophers. Thus going against the enumerations Obiefuna made as regards the characteristics of good democracy which are: "Legitimacy, Checks and Balances, Competence. Responsibility, People oriented, Active participation, Human dignity, Freedom and Productive work"4. When the leadership of a nation gets it right as was exemplified by Lee Kuan Yew in his "From Third World to First" the nation automatically gets it right. Chinua Achebe once noted in his book, The Trouble with Nigeria, that "the trouble with Nigeria is simply and squarely a failure of leadership." 5

When the leadership of a country decides to become serious, there is usually a positive result. Singapore is a case to study as regards this, Lee Kuan Yew says:

We faced tremendous odds with an improbable chance of survival, Singapore was not a natural country, but manmade, a trading post the British had developed into a nodal point in their worldwide maritime empire. We inherited the island without the hinterland, a heart without a body. ${ }^{6}$.

At the wake of democracy in 1999, marking the third republic, Nigerians became happy with high hopes, heralding the advent of the long expected dividends of democracy. This is actually where the problem lies, because what Nigerians got and are still getting was and is the direct opposite of what they expected, the politics of the end justifies the means became the order of the day, corruption is seen everywhere in all the sectors: Executive, National Assembly, Military, Police, Navy, Custom, Immigration, Judiciary, Government Ministries and so on. The level of high handedness, bribery and corruption inherent in these parastatals, is quite alarming 
Enemuo: John Locke's Concept of State: A panacea for the challenges...

and unimaginable. Survival of the fittest took over the justice system; leaders maltreat and manipulate the whole nation, state and local government as the case may be, sit tight syndrome is seen here and there, no one wants to relinquish power, politicians clamour for second term even and a possible third term even when it is crystal clear to them and all that they performed far below average in their first term.

Consequently, the scope of this work would be situated within the confines of John Locke's Concept of the State and Nigerian democracy. The work would be philosophical in nature; hence it would adopt the philosophical method of exposition as its modus operandi. This research work seeks to situate its headache on the nature and characteristics of the type of democracy practiced in Nigeria, showcasing its successes if there is and its obvious failures and makes a recommendation on how best to practice democracy in the light of John Locke's political theory, so as to effectively and adequately deliver the dividends of democracy to the poor masses of Nigerian society.

\section{John Locke's Political Theory}

John Locke's political thought is well represented in his two treatise of government, the first was actually a response to Robert Filmer, it was a critique of the absolutist position while the second treatise presents Locke's own preferred theoretical alternative which is a limited government based on popular consent.

\section{First Treatise of Civil Government}

Like I stated earlier, the first treatise is a response to Sir Robert Filmer view of authority and government in his work Patriach. Filmer actually projected that divine authority is the first and the origin of power and authority, but he ended up proposing and supporting what could be summarized as political absolutism. He buttressed his understanding of absolutism on a reading of the biblical account of creation. In his interpretation of the Old Testament, he justified patriarchal kingship and then subsequently applied such argument to the monarchies of his own day.

Adam's position in the creation, his political authority over other humans and his sovereignty which for Filmer was transferred to their 
earthly princes, supported Filmer's position of absolutism. John Locke dismissed Filmer's absolutism as worthless and argues that:

There is no evidence that Adam possessed a divinely granted royal authority. If he had it: there is no evidence that his heirs had it. If they did, the right of succession was not determined, and even if there were a divinely determined order of succession, all knowledge of it has long since perished $^{7}$.

Another important point Locke attacked here was Filmer's view that 'men are not naturally free' and the rejection of the existence of a state of nature, basing his argument that in the state of nature, men are naturally free and equal. Nevertheless, we are much concerned about John Locke's second treatise of government, because it embodies John Locke's most constructive contribution to political theory.

\section{Second Treatise of Civil Government}

The second treatise was an effort by John Locke to examine to examine what political power is and what it should be. What he implies by political power is the right to make and enforce laws. The laws implied here are basically concerned with the appropriation, regulation and preservation of property and again with the issue of central defense of the nation. The magnitude of political power is best examined by how one arrives at the corridor of power. John Locke enunciated this by stipulating a process through which one ought to arrive at power, from the state of nature, moving on to the formulation of social contract then the civil government. John Locke made effort to project a legitimate political authority not anchored on a religious belief but on a practical consensual agreement of members of the society who without coercion and free will decide to form a political society.

\section{Succinct View of the State of Nature}

Contrary to the view of Thomas Hobbes which stipulated that the state of nature is a state of war of all against all, John Locke sees the state of nature as "men living together according to reason, without a common superior on earth with authority to judge between them." 8 
Enemuo: John Locke's Concept of State: A panacea for the challenges...

Again Locke views the state of nature as "a state of perfected freedom to order their actions and disposed of their possessions and persons as they think fit, within the bounds of the law of nature." ${ }^{\text {"In }}$ this state of nature, all the powers and jurisdictions is equal and reciprocal, because the idea is that all human beings are from the same biological species. He differs from Hobbes by denying that this state of nature he tries to project is not characterized by war of all against all, nevertheless he added that "though this is a state of liberty, man has not liberty to destroy himself, or so much as any creature in his possession"10. Reason is for John Locke, what guides and informs the state of nature, reason is the fundamental point in the state of nature. John Locke however added another clause to this type of state of nature, he is of the opinion that when man violets this law of reason, man thus puts himself in a state of war which is unfortunately embedded with enmity, fight and destruction with others, and thus makes himself pugnacious to humanity. Locke submitted thus "everyman hath the right to punish the offender and be executioner of the law of nature". ${ }^{11}$ Be that as it may, Locke observed that greed and confusion might set in, in executing the punishment by each individual in the society, and by implication, war and anarchy may set in. So to avoid this state of war, make made effort to leave the state of nature out of their own volition and freewill and form a political society, thus submitting their natural rights of self-defense, rectification of injustice and so on to a common, central public authority.

\section{Social Contract Theory}

The social contract for John Locke actually constituted the introduction of the state or what one can call the political society construed as a way out for the shortcomings of the state of nature. The state is an arrangement that makes for the submission of the personal right of reasoning of the individual and the right of protecting life and property given to the individual by the state of nature, Thomas Lloyd captured this in his reflection in this words, "so to accept that a state has authority is to accept that you have a moral obligation to obey it." 12 Thus Locke submitted that "the only way whereby any one divests himself of his natural liberty is by agreeing with other men to join and unite into a community for their comfortable, safe and peaceful living "13. Social contract theory does 
not rhyme very well with the Leviathan propounded by Thomas Hobbes, in the social contract setting, contracting parties do not forgo their liberty outrightly and live in servitude as was stipulated by Hobbes. What it entails is that the contracting parties forgo their right of demanding for justice as they deem fit and thus hand the right over to a legislative power for common good. Thus people's lives, property and freedom are adequately secured. Political society for John Locke emerged when people decided to come together and be ruled by the decision of the majority.

Basically people unite together so as to ensure the adequate protection of lives and property. What Locke had in mind when he was speaking about property where namely: lives, liberty/freedom and estates. Brandishing the state of nature as an ugly situation, he enumerated some major objectives of forming a civil government. This could be summarized in the following three points.

a. Instituting a common law by common consent, to determine right and wrong.

b. Electing a known and indifferent judge with authority to deter all differences according to stipulated laws.

c. Instituting an executive power to carry out right judgments.

Which this working optimally, the common good of the people is ought to be met. However, the government which is constituted by the people has onerous task to fulfill by the different arms of government for the purpose of peace, safety and public good of the people. The legislative sees to the public good by deciding how the forces of society shall be utilized. The legislative differ from the executive, the executive is in charge of administering the law and executing the law, thus Wiser opined that "the task of administering the law and overseeing the punishment of those who disobey should be delegated to the executive." 14 The power of the executive should always be under check by the legislative, it the onus of the legislative to establish laws and principles that would guide the actions of the executive.

A very important aspect of this is that the government can be dissolved if the trust placed upon them became obviously questioned. What this means is that the government is and should be people oriented. It is based on the amount of trust that people placed 
Enemuo: John Locke's Concept of State: A panacea for the challenges...

on them. Pertinent to note here is that the relationship existing between the government and the society is fiduciary rather than a contract form. If the legislative power betrays its trust, it may be removed and the power devolved into the hands of those that gave it, who may place it in a new place, where they shall think best for their safety and security. John Locke posited two types of dissolution, namely: dissolution from within and dissolution as overturning from without. Other reasons why a government could be dissolved could be when "a prince sets up his own arbitrary will of the society, declared by the legislative, then the legislative is changed"13. Again, the government is also dissolved "when the prince hinders the legislative from assembling in its due time or from acting freely, pursuant to those ends for which it was constituted." 14 Dissolution can also occur, "when by the arbitrary power of the prince, the electorate or ways of election are altered, without the consent and contrary to the common interest of the people; there also, the legislative is altered. ${ }^{15}$ A government may also be dissolved when "the delivery also of the people into the subjection of a foreign power, either by the prince, or by the legislative" 16 . Finally, and most importantly, as it affects Nigeria, a government should be dissolved when "he who has the supreme executive power neglects and abandons that charge, so that the laws already made can no longer be put in executive."17

\section{Democracy in Nigeria}

Nigeria and her democracy have been shaky since the inception of this system of government. A lot has claimed that the problem with Nigeria was the long military rule, but a calculation from when the military handed over to the civilian since the year 1999 till date is almost twenty years which is equal to two complete decades, thus one would begin to wonder, what actually is the problem with Nigeria, is it the problem of leadership, or the problem of followership, is it the problem of attitude, or the problem of poor school curriculum, is it the problem of selfishness or people's hate for the mother land, in summarizing all these, one could say that it is basically "Institution" borrowing the word of Acemoglu and Robinson, let's get to know what they meant by this "countries differ in their economic success because of their different institutions, the rules influencing how the economy works, and the incentives that 
Ogirisi: a new journal of African studies vol. 15s 2019

motivate people."18 Basically Nigeria got it wrong because of the kind of institutions they build; the fundamental problem here is attitude. Democracy is supposed to be based on the sovereignty of the people, so it should as a matter of fact be people oriented and people driven, but the reverse is the case. Eugene Anowai thus noted that:

The pillars of democracy are sovereignty of the people, government based upon consent of the governed, majority rule, minority rights, guarantee of basic human rights, free and fair election, equality of law, due process of law, constitutional limits on government, socio-economic and political pluralism, values of tolerance" $" 19$.

It is quite pertinent to note at this point that these pillars of democracy have been recklessly neglected and that is why Nigerian democracy is in deep mess and in serious crisis. The leaders today have turned into elected dictators, with zero respect and regard for the rule of law; one begins to wonder if what Nigeria practices is another form of democracy. Theophilus Okere defined democracy as "a government where the people are perceived to be indeed the primary beneficiaries of the services of the elected," ${ }^{20}$ but what is seen is the direct opposite. It is in Nigeria that a governor can push the salaries of civil servant for one or two years to a foreign account abroad, and after having been charged by a competent court of jurisdiction, would end up getting settled with a ministerial position. The elections that usually bring in politicians to power in Nigeria are highly questionable and regrettably, it gets worse by the day. In a true democratic setting, election forms the basic means by which candidates assume power, consequently, election should be a sacred event; it should be seen and treated as a serious and sensitive affair, but what is seen is gross rigging, massive shooting, threats of baboon, fight and blood, taking power by force, and the worst part of it is that the body saddled with the responsibility of conducting free and fair election is also trapped in this mess, such that one begins to question the independency attached to the nomenclature of INEC. Truth be told, the Independency of INEC is in principle and not in practice. The worst part now is that the Nigerian security agencies now join hands with politicians in election malpractice, even some academics who are usually recruited for ad-hoc purpose of 
Enemuo: John Locke's Concept of State: A panacea for the challenges...

conducting elections are not left out in the rape of democracy, thus Theophilus Okere sees this kind of attitude as gross corruption, he describes it as "corruption both of the leaders and of the led is one virus that has infected our body politics." 21 To state how bad the concept of democracy has gone in Nigeria, Okere concluded that "so as things as things stand in Nigeria one can sum up the situation as Not Yet Democracy." 22

Talking about infrastructures and social amenities in Nigeria is like literally pouring water on top of a stone, the dividends of democracy has indeed eluded Nigeria for decades. The roads are very bad, there are no constant supply of good table water, the whole of Nigeria has resorted to sinking private water bole holes in search of water resources, sad to note here is that Nigeria is still yet to research on the adverse effect of this proliferation of boreholes being cons trusted almost within an interval of twenty to forty meters. The security agencies have indeed failed in their responsibilities, people pay double tax as regards security in Nigeria, after paying tax as a civil servant for instance at source, one still under compulsion pays what is now termed "vigilante security fee" this is what should be the primary responsibility of government through agencies like the military, police, civil defense and so on and so forth. Power or electric is usually what drives production everywhere in the world, the case of Nigeria is quite different, people get to pay through their nose for the epileptic power supply we witness here, and still provide themselves with private sources of power supply. This has regrettably made most companies to stop operation and go into extinction and or moribund. Expanding it further would have made one to see why Nigeria would not grow and become stable with her economy. Because production is difficult in Nigeria, Nigeria imports almost all the products they consume, and worthy to state here is that importation is a killer of economy; it depletes the foreign reserve of the nation and enriches the purchasing power and ability of the currency of the exporting country. Talking about government housing scheme in Nigeria would be like asking a blind man colour of the item before him. The few housing scheme that has been executed in Nigeria were either haphazardly done or where designed to scam the populace. The government has virtually failed in all her responsibilities. 
A cursory look at the Nigeria judiciary system would rather leave one activating his or her lachrymals gland. The executive does not give pride of place to the system and have zero respect for the rule of law, recall that a law is the combination of the working document that binds a group of people. So speaking differently, the law is the voice of the people. Sad to observe that the apex law outfit in Nigeria stands as a stooge to the office of the president. The various people representing the populace are also part of Nigerian's poor democratic system. Senators and members of Reps collect constituency allowance and convert same to private property and that is why Nigeria is where she is. Education in Nigeria is on the fast pedestal of decline, because the government of Nigeria has blatantly refused to budget more value annually on education, that is why you see things get worse on daily basis, because the word education means to lead one out of darkness.

Human right and social justice has no more place in the hearts of most Nigerians. People at the helm of affairs use their position to convict and jail their political opponents. On the various Nigerian roads, the police and the military has vowed to keep on embarrassing citizens with every amount impunity, causing more problem than they are charged to curb. Inter-party wars are taken to the extreme, once one does not belong to the party; one is perceived as an enemy and thus is fought with every amount of energy and facility available.

\section{Summary and Conclusion}

All these issues and many more are the reasons why men gather together to form a civil government. When one gives up his life for fending for himself and defending his private property, one expects that the function and the submission would be adequately treated, but the opposite exists in Nigeria. When the role of the government has been seen to be absent, there should certainly be mayhem in the polis/city or state if you like. The reason why people gave up their power to a supposed civil government is for a general protection of their life and property, but in a case where the government has obviously reneged in her duty, then the purpose is defeated and John Locke stipulated dissolution of the state. From every indication, Nigeria is very close to the brink of disaster and dissolution is what the clock ticks, if the current Nigerian leaders do not brace up and 
Enemuo: John Locke's Concept of State: A panacea for the challenges...

live up to their responsibilities, then a revolution might be an unavoidable impending danger and this as it were, would not fetch anybody anything good. The people who are supposed to be the rulers according to the definition of democracy, people who are supposed to be at the center of democracy, are now at the receiving end. Consequently, the democracy in Nigeria has been very faulty and on the brink of collapse if conscious effort is not made by the government to go back to the drawing board.

\section{*John-Paul Chinedu Enemuo}

Department of Philosophy

Nnamdi Azikiwe University, Awka.

Email-reachbaron@yahoo.com 


\section{References}

1. S.E. Stumph, Philosophy: History and Problems, $5^{\text {th }}$ Edition, New York: McGraw Hill-Inc, 1994, p.103

2 .Ibid

3. B. Obiefuna, 'Human Work for Sustainable Development in Nigeria' in WAJOPS Vol. 9, 2006, P. 49.

4. B. Russel, History of Western Philosophy, (London: Routledge, 2004) p. 509

4. C. Achebe, The Trouble with Nigeria, http://africanbookaddict.com (accessed Dec 12, 2019) P.1

5. L. Kuan Yew, From Third World to First: Singapore and the Asian Economic Boom (USA: HarperCollins, 2011) P. 3

6. J.L. Wiser, Political Philosophy of the Search for Order, USA: Prentice-Hall Inc., Englewood Cliffs, 1983, P. 218

7. J. Locke, Second Treatise on Government, Ch. IX, P. 66

8 .Ibid. P. 11

9. Ibid. P. 4

10. Ibid. P.5

11. Ibid. P.49

12. J.L. Wiser, Op Cit., P.226

13. D.A Lloyd Thomas, Routledge Philosophy GuideBook To Locke on Government, USA \& Canada, 1998, P.54

14. J. Locke, Op Cit. P.107

15. Ibid

16. Ibid

17. Ibid

18. Ibid. P.109

19. D. Acemoglu \& J. Robinson, Why Nations Fail: The Origin of Power, Prosperity and Power. Profile Books Ltd 2013 P.73

20. E. Anowai, Nigerian Democracy in Crisis: Who is Guilty? Focus Magazine, No 8 Dec 2006, P.17

21. T. Okere, The People as the Primary Beneficiary of the Services of the Elected, in Okere in His Own Words: The Hermeneutics of Culture, Religion and Society, ed. J.Oguejiofor, Four Colour Print Group Kentucky USA. 2015 P. 202

22. T. Okere, Crisis of Governance in Africa: The Root of the Problem, Op Cit P.20

23. T. Okere, Democracy in Nigeria, Op Cit P.215. 